
RESEARCH AND DEVELOPMENT

\author{
http://journal.unnes.ac.id/sju/index.php/higeia
}

\title{
PEMANFAATAN KARTU JKN-KIS PADA PASIEN RAWAT INAP DI RSUD UNGARAN
}

\author{
Harizatul Qudsiah ${ }^{\bowtie}$, Fitri Indrawati
}

Administrasi Kebijakqan Kesehatan, Jurusan Ilmu Kesehatan Masyarakat, Fakultas Ilmu Keolahragaan, Univeritas Negeri Semarang

\section{Info Artikel \\ Sejarah Artikel: \\ Diterima Februari 2018 \\ Disetujui Maret 2018 \\ Dipublikasikan April \\ 2018}

Keywords:

Use of JKN-KIS card,

Patient, Hospital inpatient

\begin{abstract}
Abstrak
Angka kunjungan pasien rawat inap di RSUD Ungaran tahun 2014-2016 lebih tinggi dibanding RSUD Ambarawa namun angka presentase pemanfaatan JKN-KIS di RSUD Ungaran lebih rendah dibanding RSUD Ambarawa yaitu sebanyak 39,8\% sedangkan RSUD Ambarawa sebanyak $47,14 \%$. Tujuan penelitian untuk menganalisis faktor yang berhubungan dengan pemanfaatan kartu JKN-KIS pada pasien rawat inap di RSUD Ungaran. Jenis penelitian merupakan penelitian observasional analitik dengan rancangan cross sectional. Sampel penelitian yaitu 75 responden dengan teknik cluster sampling. Data dianalisis univariat dan bivariat dengan menggunakan uji chi-square. Hasil menunjukkan bahwa pekerjaan ( $\mathrm{PR}=0,711 ; 95 \% \mathrm{CI}=0,520$ 0,972), pengetahuan ( $\mathrm{PR}=2,188 ; 95 \% \mathrm{CI}=1,252-3,822)$, sikap ( $\mathrm{PR}=3,923 ; 95 \% \mathrm{CI}=1,128-13,64)$, persepsi ( $\mathrm{PR}=2,188$; 95\% $\mathrm{CI}=1,252-3,822)$, promosi ( $\mathrm{PR}=1,492 ; 95 \% \mathrm{CI}=1,053-2,114)$, kepuasan terhadap pelayanan kesehatan $(\mathrm{PR}=0,705 ; 95 \% \quad \mathrm{CI}=0,543-0,915)$ berhubungan dengan pemanfaatan kartu JKN-KIS pada pasien rawat inap di RSUD Ungaran. Sedangkan tingkat pendidikan ( $\mathrm{PR}=1,020 ; 95 \% \mathrm{CI}=0,762-1,366)$ dan tingkat pendapatan $(\mathrm{PR}=0,882 ; 95 \% \mathrm{CI}=0,649$ 1,197) tidak berhubungan dengan pemanfaatan kartu JKN-KIS pada pasien rawat inap di RSUD Ungaran. Faktor yang paling dominan dengan pemanfaatan kartu JKN-KIS adalah sikap.
\end{abstract}

\begin{abstract}
The number of inpatient visit at RSUD Ungaran in 2014-2016 was higher than RSUD Ambarawa, but the percentage of the using of JKN-KIS card at RSUD Ungaran was lower than RSUD Ambarawa which was 39,8\%, while RSUD Ambarawa was 47,14\%. This research aimed to analyze the factors which correlated with the inpatient using of JKN-KIS cards at RSUD Ungaran. The research was analytical observational with cross sectional design. 75 respondents are stated as the sample which use cluster sampling technique. The data were analized unvariete and bivariete using chi-square test. The results shown that occupation $(P R=0,711$; 95\% $C I=0,520-0,972)$, acknowledge ( $P R=2,188 ; 95 \% C I=1,252-3,822)$, behaviour $(P R=3,923 ; 95 \%$ $C I=1,128-13,64)$, perception $(P R=2,188$; 95\% $C I=1,252-3,822)$, promotion $(P R=1,492 ; 95 \% C I=1,053$ $2,114)$, and satisfaction to health service ( $P R=0,705 ; 95 \% C I=0,543-0,915)$ were correlated with the patient usage of JKN-KIS cards at RSUD Ungaran. Education level (PR=1,020; 95\% CI=0,762-1,366) and income rate $(P R=0,882 ; 95 \% C I=0,649-1,197)$ irrelated with the patient usage of JKN-KIS cards at RSUD Ungaran. The most dominant factor with the patient usage of JKN-KIS card was behavior.
\end{abstract}

(C) 2018 Universitas Negeri Semarang

Alamat korespondensi:

Gedung F5 Lantai 2 FIK Unnes

p ISSN 1475-362846

Kampus Sekaran, Gunungpati, Semarang, 50229

e ISSN 1475-222656 


\section{PENDAHULUAN}

Kesehatan merupakan hak asasi manusia dan salah satu unsur kesejahteraan yang harus diwujudkan sesuai dengan cita-cita bangsa Indonesia sebagaimana dimaksud dalam Pancasila dan Undang-Undang Dasar Negara Republik Indonesia Tahun 1945. Setiap kegiatan dalam upaya memelihara dan meningkatkan derajat kesehatan masyarakat yang setinggi-tingginya dilaksanakan berdasarkan prinsip nondiskriminasi, partisipatif, dan berkelanjutan dalam rangka pembentukan sumber daya manusia Indonesia, serta peningkatan ketahanan dan daya saing bangsa bagi pembangunan nasional (Kementerian Kesehatan RI, 2009).

Salah satu penyelenggara pelayanan kesehatan adalah rumah sakit. American Hospital Association mengatakan bahwa rumah sakit adalah institusi yang fungsi utamanya adalah memberikan pelayanan kepada pasien baik diagnostik maupun terapeutik, untuk berbagai penyakit dan masalah kesehatan, baik yang bersifat bedah maupun nonbedah. Salah satu pelayanan kesehatan di rumah sakit yaitu pelayanan rawat inap, sesuai dengan isi UU No. 44 Tahun 2009 tentang rumah sakit yang menyebutkan bahwa rumah sakit memberikan pelayanan rawat inap, rawat jalan maupun gawat darurat. Rawat inap adalah pemeliharaan kesehatan rumah sakit dimana penderita tinggal/mondok sedikitnya satu hari berdasarkan rujukan dari pelaksana pelayanan kesehatan atau rumah sakit pelaksana pelayanan kesehatan lain (American Hospital Association, 1978 dalam Winardi, 2014).

Badan Penyelenggara Jaminan Sosial (BPJS) merupakan lembaga yang dibentuk untuk menyelenggarakan Program Jaminan Kesehatan Nasional (JKN) di Indonesia dan merupakan badan hukum nirlaba. BPJS merupakan transformasi dari sejumlah badan usaha milik negara (BUMN) yaitu diantaranya lembaga asuransi jaminan kesehatan PT. Askes (Persero) menjadi BPJS Kesehatan dan lembaga jaminan sosial ketenagakerjaan PT. Jamsostek (Persero) menjadi BPJS Ketenagakerjaan.
Peserta BPJS Kesehatan dibagi menjadi dua yaitu PBI (Penerima Bantuan Iuran) dan bukan PBI atau non PBI. Peserta PBI iurannya ditanggung pemerintah, sedangkan non PBI terdiri dari pekerja penerima upah dan anggota keluarganya, pekerja bukan peneriman upah dan anggota keluarganya. Data dari Badan Pusat Statistik Jawa Tengah (BPS Jawa Tengah) tahun 2016, jumlah peserta BPJS Kesehatan Kabupaten Semarang tahun 2016 sebanyak 601.830 orang atau $62,6 \%$ dari jumlah penduduk Kabupaten Semarang, terdiri dari PBI sebanyak 324.820 orang $(53,97 \%)$ dan non PBI sebanyak 277.010 jiwa (46,03\%).

Di antara beberapa rumah sakit di Kabupaten Semarang, peneliti melakukan studi pendahuluan di dua rumah sakit di Kabupaten Semarang dengan karakteristik dan tipe rumah sakit yang sama yaitu tipe C, yakni di Rumah Sakit Umum Daerah (RSUD) Ungaran dan RSUD Ambarawa. Hasil studi pendahuluan yang dilakukan oleh peneliti diketahui bahwa jumlah kunjungan pasien rawat inap di RSUD Ungaran Kabupaten Semarang selama tiga tahun terakhir (2014-2016) adalah sebanyak 46.266 pasien, dengan pasien umum sebanyak $60,2 \%$ dan pasien JKN-KIS sebanyak 39,8\%. Sedangkan jumlah kunjungan pasien rawat inap di RSUD Ambarawa Kabupaten Semarang adalah 43.423 pasien dengan pasien umum sebanyak $52,86 \%$ dan pasien JKN-KIS sudah sebanyak 47,14\%.

Pada tahun 2016 angka penggunaan JKN-KIS di RSUD Ungaran sebesar 49,69\% terdiri dari pasien JKN-KIS PBI sebanyak $13,418 \%$ dan pasien JKN-KIS non PBI sebanyak 36,278\%. Sedangkan angka penggunaan JKN-KIS di RSUD Ambarawa pada tahun 2016 sudah sebesar 76,54\% dengan pasien JKN-KIS PBI sebasar $17,42 \%$ dan pasien JKN-KIS non PBI sebesar 59,12\%. Dari data tersebut diketahui bahwa pemanfaatan JKNKIS di RSUD Ungaran lebih rendah dibanding RSUD Ambarawa.

Berdasarkan hasil penelitian yang dilakukan oleh Quimbo (2008), pendidikan berhubungan dengan pemanfaatan asuransi kesehatan sosial di rumah sakit di Filipina dan 
pengajuan klaim asuransi dipengaruhi oleh pengetahuan dan pemahaman seseorang terhadap suatu produk. Menurut penelitian Sampeluna (2013), responden yang bekerja lebih banyak memanfaatkan pelayanan kesehatan di rumah sakit dibandingkan yang tidak memanfaatkan yaitu sebanyak $76 \%$. Selain itu, pendapatan juga berpengaruh pada daya beli pasien terhadap pelayanan kesehatan dan menentukan jenis pelayanan yang dikehendaki.

Penelitian yang dilakukan oleh Melinda (2016), menunjukkan ada hubungan antara sikap responden dengan minat keikutsertaan responden dalam BPJS Kesehatan, semakin besar sikap mendukung terhadap BPJS Kesehatan maka semakin besar kemungkinan minat dalam keikutsertaan BPJS Kesehatan dan dengan demikian, semakin besar kemungkinan memanfaatkan BPJS Kesehatan untuk memperoleh pelayanan kesehatan di rumah sakit. Menurut penelitian Melinda (2016), terdapat hubungan antara persepsi dengan minat keikutsertaan BPJS Kesehatan. Responden dengan persepsi baik kemungkinan untuk berminat dalam keikutsertaan BPJS sebesar 7,9 kali lebih besar dibanding responden dengan persepsi kurang baik.

Berdasarkan penelitian Tumbuan (2016), terdapat hubungan antara promosi BPJS Kesehatan dengan pemanfaatan layanan BPJS Kesehatan di RSUD Amurang dengan $p$ value $0,000(p<0,05)$. Pada penelitian Septianingrum (2015), sebagian besar ibu hamil tidak menggunakan kartu JKN-KIS karena minimnya penyuluhan tentang Jaminan Kesehatan Nasional di wilayah Desa Sobokerto. Menurut penelitian yang dilakukan oleh Putri (2014) bahwa pengguna kartu JKN-KIS kategori PBI tidak mau mengurus pemanfaatan kartu JKNKIS karena memiliki pengalaman yang kurang baik dengan produk jaminan kesehatan terdahulu seperti Jamkesmas dan Jamkesda, sehingga kepuasan pasien berpengaruh terhadap pemanfaatan layanan BPJS Kesehatan.

Tujuan penelitian ini adalah ntuk meneliti tentang faktor-faktor yang berhubungan dengan pemanfaatan kartu JKN-KIS pada pasien rawat inap.

\section{METODE}

Penelitian ini menggunakan jenis penelitian observasional dengan menggunakan studi analitik. Rancangan penelitian yang digunakan yaitu cross sectional. Penelitian dilaksanakan selama satu bulan yaitu pada bulan Oktober sampai November 2017 di RSUD Ungaran.

Variabel bebas dalam penelitian ini adalah tingkat pendidikan, pekerjaan, tingkat pendapatan, pengetahuan, sikap, persepsi tentang Program JKN, kepemilikan kartu JKNKIS, status keaktifan kartu JKN-KIS, promosi BPJS Kesehatan, dan kepuasan terhadap pelayanan kesehatan, sedangkan variabel terikat dalam penelitian ini adalah pemanfaatan kartu JKN-KIS pada pasien rawat inap Rumah Sakit Umum Daerah (RSUD) Ungaran.

Populasi dalam penelitian ini adalah semua pasien pada unit rawat inap RSUD Ungaran yang dihitung berdasarkan jumlah pasien pada tahun 2016 yaitu sebanyak 13.712 orang. Besar sampel minimal yang didapat berdasarkan rumus perhitungan sampel minimal dari Isaac dan Michael untuk tingkat kesalahan $1 \%$, 5\%, dan 10\% (Sugiyono, 2010). Maka diperoleh besar sampel minimal sebesar 67 orang, kemudian ditambahkan spare $10 \%$ maka besar sampel penelitian ini adalah 75 orang. Pengambilan sampel dilakukan dengan teknik cluster sampling. Teknik cluster sampling dengan mengelompokkan responden berdasarkan ruang perawatan. Teknik cluster sampling dilakukan dengan cara (1) menentukan berapa banyak sampel yang diambil dari tiap-tiap ruang perawatan yang menjadi tempat penelitian, dihitung dengan membagi jumlah pasien per ruang dengan seluruh pasien rawat inap di RSUD Ungaran (13.712 orang) kemudian hasilnya dikalikan dengan jumlah sampel (75 orang); (2) berdasarkan perhitungan tersebut peneliti menentukan jumlah sampel di masingmasing ruang perawatan; (3) kemudian peneliti mengambil sampel di setiap ruang perawatan yang ada di RSUD Ungaran yang sesuai dengan kriteria inklusi sehingga didapatkan hasil, yaitu Ruang Dahlia sebanyak 18 responden, Ruang 
Cempaka sebanyak 15 responden, Ruang Mawar sebanyak 18 responden, Ruang Bugenvil sebanyak 16 responden, dan Ruang Anggrek sebanyak 8 responden. Kriteria inklusi dalam penelitian ini adalah responden merupakan pasien rawat inap usia 15 sampai 60 tahun; pasien rawat inap dalam keadaan sadar dan mampu diajak berkomunikasi; dan kooperatif, sedangkan kriteria eksklusi dalam penelitian ini yaitu tidak bersedia menjadi responden; responden dalam tindakan khusus (keadaan emergency); dan terdapat keadaan yang mengganggu penelitian (seperti kecelakaan).

Sumber data adalah data primer dan data sekunder. Pengumpulan data primer diperoleh melalui wawancara langsung kepada pasien/responden dan data sekunder diperoleh dari BPS Jawa Tengah terkait data jumlah penduduk dan jumlah peserta BPJS Kesehatan di Kabupaten Semarang, RSUD Ungaran terkait data kunjungan rawat inap yang didapat dari unit rekam medis, dan referensi lain yang berhubungan (buku, undang-undang, jurnal penelitian, skripsi/tesis, media massa, dan informasi yang didapat dari internet).

Instrumen penelitian menggunakan kuesioner. Kuesioner ini digunakan untuk mendapatkan informasi tentang variabel yang diteliti berupa tingkat pendidikan, pekerjaan, tingkat pendapatan, pengetahuan, sikap, persepsi tentang Program JKN, kepemilikan kartu JKN-KIS, status keaktifan kartu JKNKIS, promosi BPJS Kesehatan, kepuasan terhadap pelayanan kesehatan. Teknik pengambilan data dilakukan dengan wawancara langsung kepada responden. Penelitian ini menggunakan uji validitas dan uji reliabilitas untuk menguji validitas dan reliabilitas instrumen. $\mathrm{Uji}$ validitas dan reliabilitas dilakukan pada 30 responden di luar responden penelitian. Peneliti melakukan uji validitas dan reliabilitas di tempat yang memiliki karakteristik hampir sama dengan tempat penelitian atau RSUD Ungaran yaitu di RSUD Ambarawa.

Analisis data menggunakan analisis univariat dan bivariat dengan menggunakan uji chi square dan uji fisher untuk variabel dengan data yang memiliki nilai expected count $<5$.

\section{HASIL DAN PEMBAHASAN}

Hasil penelitian yang dilakukan pada bulan Oktober sampai November 2017 di Ruang Dahlia, Ruang Cempaka, Ruang Mawar, Ruang Bugenvil, dan Ruang Anggrek yang merupakan ruang rawat inap RSUD Ungaran, didapatkan hasil karakteristik responden dalam penelitian ini meliputi jenis kelamin, umur, status pasien, dan ruang perawatan. Kemudian akan dibahas mengenai hasil analisis bivariat berupa hubungan antar variabel penelitian (variabel bebas dan variabel terikat).

Berdasarkan tabel 1 diketahui bahwa karakteristik responden berdasarkan hasil survei jenis kelamin pada pasien rawat inap di RSUD Ungaran menunjukkan bahwa jumlah responden dengan jenis kelamin perempuan lebih banyak dibandingkan dengan laki-laki

Tabel 1. Karakteristik Responden

\begin{tabular}{lcc}
\hline \multirow{2}{*}{ Karakteristik } & \multicolumn{2}{c}{ Frekuensi } \\
\cline { 2 - 3 } Jenis Kelamin & $\mathrm{n}$ & $\%$ \\
Laki-laki & 24 & 32 \\
Perempuan & 51 & 68 \\
Total & 75 & 100 \\
Umur (tahun) & & \\
15-24 & 17 & 22,7 \\
25-33 & 5 & 6,7 \\
34-42 & 19 & 25,3 \\
43-51 & 12 & 16 \\
52-60 & 22 & 29,3 \\
Total & 75 & 100 \\
Status Pasien & & \\
Umum & 23 & 30,7 \\
JKN-KIS & 52 & 69,3 \\
Total & 75 & 100 \\
Ruang Perawatan & & \\
Dahlia & 18 & 24 \\
Cempaka & 15 & 20 \\
Mawar & 18 & 24 \\
Bugenvil & 16 & 21,3 \\
Anggrek & 8 & 10,7 \\
Total & 75 & 100 \\
\hline
\end{tabular}


yaitu sebanyak 51 orang (68\%) dan jenis kelamin laki-laki sebanyak 24 orang (32\%). Distribusi responden menurut umur memperlihatkan bahwa paling banyak responden berusia 52-60 tahun yaitu sebanyak 22 orang $(29,3 \%)$ dan paling sedikit responden berusia 25-33 tahun yaitu sebanyak 5 orang $(6,7 \%)$. Distribusi responden berdasarkan status pasien menunjukkan bahwa pasien umum lebih sedikit dibandingkan dengan pasien JKN-KIS yaitu sebanyak 23 orang $(30,7 \%)$ dan pasien JKN-KIS sebanyak 52 orang $(69,3 \%)$. Distribusi responden berdasarkan ruang perawatan terse- bar di Ruang Dahlia sebanyak 18 orang (24\%), Ruang Cempaka sebanyak 15 orang (20\%), Ruang Mawar sebanyak 18 orang (24\%), Ruang Bugenvil sebanyak 16 orang $(21,3 \%)$, dan Ruang Anggrek sebanyak 8 orang (10,7\%).

Berdasarkan tabel 2 diketahui bahwa hasil analisis bivariat yang dilakukan pada variabel tingkat pendidikan menunjukkan secara statistik bahwa tingkat pendidikan tidak berhubungan dengan pemanfaatan kartu JKN-KIS. Hasil uji chi square diperoleh nilai $p(1,000)>\alpha(0,05)$. Dengan interval kepercayaan 0,762-1,366 (mencakup nilai 1), sehingga $\mathrm{Ho}$ diterima $\mathrm{Ha}$

Tabel 2. Hasil Analisis Bivariat dengan Menggunakan Uji Chi Square

\begin{tabular}{|c|c|c|c|c|c|c|c|c|c|}
\hline \multirow{3}{*}{ Variabel } & \multirow{3}{*}{ Kategori } & \multicolumn{4}{|c|}{ Pemanfaatan JKN-KIS } & \multirow{2}{*}{\multicolumn{2}{|c|}{ Jumlah }} & \multirow{3}{*}{$\begin{array}{c}\mathrm{PR}(95 \% \\
\text { C.I) }\end{array}$} & \multirow{3}{*}{$p$ value } \\
\hline & & \multicolumn{2}{|c|}{$\mathrm{Ya}$} & \multicolumn{2}{|c|}{ Tidak } & & & & \\
\hline & & $\mathrm{n}$ & $\%$ & $\mathrm{n}$ & $\%$ & $\mathrm{n}$ & $\%$ & & \\
\hline Tingkat & Tinggi & 25 & 33 & 10 & 13 & 35 & 47 & 1,020 & 1,000 \\
\hline Pendidikan & Rendah & 28 & 37 & 12 & 16 & 40 & 53 & $\begin{array}{l}(0,762- \\
1,366)\end{array}$ & \\
\hline \multirow[t]{2}{*}{ Pekerjaan } & Bekerja & 21 & 28 & 15 & 20 & 36 & 48 & \multirow{2}{*}{$\begin{array}{c}0,711 \\
(0,520- \\
0,972)\end{array}$} & \multirow[t]{2}{*}{0,045} \\
\hline & $\begin{array}{c}\text { Tidak } \\
\text { Bekerja }\end{array}$ & 32 & 43 & 7 & 9,3 & 39 & 52 & & \\
\hline Tingkat & Rendah & 21 & 28 & 11 & 15 & 32 & 43 & 0,882 & 0,568 \\
\hline Pendapatan & Tinggi & 32 & 43 & 11 & 15 & 43 & 57 & $\begin{array}{l}(0,649- \\
1,197)\end{array}$ & \\
\hline \multirow[t]{2}{*}{ Pengetahuan } & Tinggi & 45 & 60 & 9 & 12 & 54 & 72 & 2,188 & 0,000 \\
\hline & Rendah & 8 & 11 & 13 & 17 & 21 & 28 & $\begin{array}{l}(1,252- \\
3,822)\end{array}$ & \\
\hline \multirow[t]{2}{*}{ Sikap } & Setuju & 51 & 68 & 14 & 19 & 65 & 87 & \multirow{2}{*}{$\begin{array}{c}3,923 \\
(1,128- \\
13,64)\end{array}$} & \multirow[t]{2}{*}{0,001} \\
\hline & $\begin{array}{l}\text { Tidak } \\
\text { Setuju }\end{array}$ & 2 & 2,7 & 8 & 11 & 10 & 13 & & \\
\hline \multirow[t]{2}{*}{ Persepsi } & Baik & 45 & 60 & 9 & 12 & 54 & 72 & \multirow{6}{*}{$\begin{array}{c}2,188 \\
(1,252- \\
3,822)\end{array}$} & \multirow[t]{2}{*}{0,000} \\
\hline & Buruk & 8 & 11 & 13 & 17 & 21 & 28 & & \\
\hline Kepemilikan & $\mathrm{Ya}$ & 53 & 71 & 6 & 8 & 59 & 79 & & \\
\hline JKN-KIS & Tidak & 0 & 0 & 16 & 21 & 16 & 21 & & \\
\hline Status & Aktif & 53 & 71 & 3 & 4 & 56 & 75 & & \\
\hline $\begin{array}{l}\text { Keaktifan } \\
\text { JKN-KIS }\end{array}$ & $\begin{array}{l}\text { Tidak } \\
\text { Aktif }\end{array}$ & 0 & 0 & 19 & 25 & 19 & 25 & & \\
\hline \multirow[t]{2}{*}{ Promosi } & Pernah & 36 & 48 & 8 & 11 & 44 & 59 & \multirow{2}{*}{$\begin{array}{c}1,492 \\
(1,053- \\
2,114)\end{array}$} & \multirow[t]{2}{*}{0,023} \\
\hline & $\begin{array}{l}\text { Tidak } \\
\text { Pernah }\end{array}$ & 17 & 23 & 14 & 19 & 31 & 41 & & \\
\hline \multirow{2}{*}{$\begin{array}{l}\text { Kepuasan } \\
\text { Pelayanan } \\
\text { Kesehatan }\end{array}$} & Puas & 31 & 41 & 19 & 25 & 50 & 67 & \multirow{2}{*}{$\begin{array}{c}0,705 \\
(0,543- \\
0,915)\end{array}$} & \multirow[t]{2}{*}{0,039} \\
\hline & $\begin{array}{l}\text { Cukup } \\
\text { Puas }\end{array}$ & 22 & 29 & 3 & 4 & 25 & 33 & & \\
\hline
\end{tabular}


ditolak yang artinya tidak ada hubungan antara tingkat pendidikan dengan pemanfaatan kartu JKN-KIS pada pasien rawat inap di RSUD Ungaran. Nilai PR (Prevalence Ratio) adalah 1,020 , artinya pasien rawat inap dengan tingkat pendidikan tinggi memiliki peluang 1,020 kali untuk memanfaatkan kartu JKN-KIS di RSUD Ungaran. Penelitian ini sejalan dengan hasil penelitian Rumengan (2015) yang dilakukan di Kecamatan Mapanget Kota Manado yang menunjukkan bahwa pendidikan tidak ada hubungan dengan pemanfaatan pelayanan kesehatan $(p=0,432)$. Menurut hasil penelitian, diketahui bahwa responden dengan pendidikan rendah lebih banyak dibandingkan dengan pendidikan tinggi yaitu sebanyak $53,3 \%$ dan $70 \%$ responden diantaranya sudah memanfaatkan kartu JKN-KIS, sehingga tingkat pendidikan tidak berhubungan dengan pemanfaatan kartu JKN-KIS pada pasien rawat inap di RSUD Ungaran. Penelitian ini bertolak belakang dengan penelitian Quimbo (2008) yang menunjukkan bahwa pendidikan berhubungan dengan pemanfaatan asuransi kesehatan sosial di rumah sakit di Filipina.

Pada variabel pekerjaan di tabel 2 diketahui bahwa jumlah responden yang bekerja lebih banyak dibandingkan dengan responden yang tidak bekerja yaitu $52 \%$ dan $48 \%$. Hasil ini sesuai dengan penelitian Alfiati (2010) tentang faktor-faktor yang mempengaruhi pemanfaatan pelayanan poli obsgyn di RSUD Banjarnegara bahwa responden yang bekerja lebih banyak dibandingkan responden yang tidak bekerja yaitu hanya $5 \%$ dari total responden. Berdasarkan hasil analisis bivariat yang dilakukan pada variabel pekerjaan menunjukkan secara statistik pekerjaan berhubungan dengan pemanfaatan kartu JKNKIS. Hal ini ditunjukkan dari hasil uji chi square diperoleh nilai $p(0,045)<\alpha(0,05)$ dan interval kepercayaan 0,520-0,972 (tidak mencakup nilai 1), sehingga $\mathrm{Ha}$ diterima Ho ditolak yang artinya ada hubungan antara pekerjaan dengan pemanfaatan kartu JKN-KIS pada pasien rawat inap di RSUD Ungaran. Penelitian ini sesuai dengan penelitian Sampeluna (2013) bahwa responden yang bekerja lebih banyak memanfaatkan pelayanan kesehatan di rumah sakit daripada yang tidak memanfaatkan. Menurut hasil penelitian Supariani (2011), menunjukkan bahwa adanya hubungan yang bermakna antara pekerjaan dengan pemanfaatan pelayanan kesehatan gigi dan mulut di rumah sakit. Seseorang yang bekerja dan berpenghasilan sendiri akan termotivasi dan bertindak untuk lebih banyak dalam memanfaatkan pelayanan kesehatan di rumah sakit, karena mereka sudah mampu membayar sendiri dalam hal ini mampu membayar iuran/premi JKN-KIS tiap bulan. Sehingga, pekerjaan merupakan faktor yang berhubungan dengan pemanfaatan kartu JKN-KIS pada pasien rawat inap di RSUD Ungaran.

Berdasarkan hasil analisis di tabel 2, diketahui bahwa pada variabel tingkat pendapatan diketahui nilai $p(0,045)<\alpha(0,05)$ dengan interval kepercayaan 0,649 - 1,197 (mencakup nilai 1), maka Ho diterima $\mathrm{Ha}$ ditolak yang artinya tidak ada hubungan antara tingkat pendapatan dengan pemanfaatan kartu JKN-KIS dan diperoleh nilai PR (Prevalence Ratio) sebesar 0,882 , artinya pasien dengan tingkat pendapatan rendah memiliki peluang 0,882 kali untuk memanfaatkan kartu JKN-KIS di RSUD Ungaran. Hasil penelitian ini sesuai dengan hasil penelitian Sampeluna (2013) yang menunjukkan bahwa pendapatan tidak berhubungan dengan pemanfaatan pelayanan kesehatan di RSUD Lakipadada Kabupaten Tana Toraja dengan nilai $p$-value $0,561(p>0,05)$.

Adanya pelayanan bagi peserta askes, jamkesmas, dan JKN-KIS menjadi daya tarik bagi masyarakat untuk memanfaatkan pelayanan kesehatan di rumah sakit sehingga walaupun sebagian besar masyarakat mempunyai pendapatan yang tinggi, mereka tetap memilih memanfaatkan pelayanan kesehatan dengan JKN-KIS karena mereka merasa sudah membayar premi setiap bulan sehingga apabila tidak dimanfaatkan mereka merasa rugi. Tingkat pendapatan memang bukanlah jaminan dapat menentukan atau memilih tempat dan jenis pelayanan kesehatan yang tepat karena ada faktor lain yang berhubungan selain pendapatan yang turut 
menentukan pemilihan pelayanan kesehatan seperti faktor umur, jenis kelamin, pendidikan, status perkawinan, pengaruh keluarga, budaya serta kemudahan dalam mengunjungi layanan kesehatan (Noor, 2008 dalam Rumengan, 2015).

Hasil analisis bivariat pada variabel pengetahuan diketahui bahwa nilai $p(0,000)<\alpha$ $(0,05)$ dengan interval kepercayaan 1,252 3,822 (tidak mencakup angka 1), yang artinya ada hubungan antara pengetahuan dengan pemanfaatan kartu JKN-KIS dan diperoleh nilai PR (Prevalence Ratio) sebesar 2,188, artinya pasien dengan pengetahuan tinggi tentang Program JKN memiliki peluang 2,188 kali untuk untuk memanfaatkan kartu JKN-KIS di RSUD Ungaran. Penelitian ini sejalan dengan penelitian yang dilakukan oleh Tumbuan (2016) bahwa terdapat hubungan antara pengetahuan pasien dengan pemanfaatan layanan BPJS Kesehatan $(p=0,003)$. Ketika pengetahuan berpengaruh terhadap perilaku seseorang, maka apabila seseorang memiliki pengetahuan yang baik tentang layanan BPJS Kesehatan dapat menimbulkan perilaku dalam bentuk pemanfaatan layanan BPJS Kesehatan. Sehingga, terdapat hubungan antara pengetahuan dengan pemanfaatan kartu JKNKIS pada pasien rawat inap di RSUD Ungaran. Pengetahuan responden tentang pencarian pengobatan kemungkinan dapat dipengaruhi oleh banyak faktor, misalnya pengalaman, serta sarana prasarana informasi. Pengetahuan tidak hanya didapat secara formal melainkan juga melalui pengalaman, selain itu pengetahuan juga didapat melalui sarana informasi yang tersedia seperti internet, radio, leaflet, dan sebagainya (Pratiwi, 2017).

Hasil analisis pada tabel 2 di atas, diketahui bahwa pada variabel sikap diketahui bahwa nilai $p(0,001)<\alpha(0,05)$ dan interval kepercayaan 1,128-13,64 (tidak mencakup angka 1), yang artinya ada hubungan antara sikap dengan pemanfaatan kartu JKN-KIS dan diperoleh nilai PR (Prevalence Ratio) sebesar 3,923 , yang artinya pasien dengan sikap setuju terhadap Program JKN memiliki peluang 3,923 kali untuk memanfaatkan kartu JKN-KIS di
RSUD Ungaran. Hasil penelitian menunjukkan sebagian besar responden memiliki sikap setuju yaitu sebanyak $86,7 \%$ dan $68 \%$ diantaranya memanfaatkan kartu JKN-KIS. Sehingga semakin besar sikap mendukung terhadap Program JKN semakin besar peluang untuk memanfaatkan kartu JKN-KIS untuk memperoleh pelayanan kesehatan di rumah sakit. Hasil penelitian ini sejalan dengan hasil penelitian Vianey (2016) bahwa terdapat hubungan antara sikap peserta BPJS dengan motivasi berobat $(p=0,000)$. Sikap diperoleh lewat pengalaman akan menimbulkan pengaruh berikutnya. Pengaruh langsung tersebut berupa motivasi yang akan direalisasikan apabila kondisi dan situasi memungkinkan. Sehingga terdapat hubungan antara sikap dengan pemanfaatan kartu JKN-KIS pada pasien rawat inap di RSUD Ungaran.

Hasil analisis bivariat pada variabel persepsi diketahui bahwa nilai $p(0,000)<\alpha$ $(0,05)$ dan interval kepercayaan 1,252-3,822 (tidak mencakup angka 1), yang artinya ada hubungan antara persepsi tentang Program JKN dengan pemanfaatan kartu JKN-KIS dan diperoleh nilai PR (Prevalence Ratio) sebesar 2,188, artinya pasien dengan persepsi baik tentang Program JKN memiliki peluang 2,188 kali untuk memanfaatkan kartu JKN-KIS di RSUD Ungaran. Dalam penelitian ini diketahui bahwa responden dengan persepsi baik tentang Program JKN sebanyak 54 responden (72\%) dan 45 responden (60\%) diantaranya sudah memanfaatkan kartu JKN-KIS, sedangkan dari 21 responden (28\%) dengan persepsi buruk hanya 8 responden $(10,7 \%)$ yang sudah memanfaatkan kartu JKN-KIS. Hal ini menunjukkan bahwa responden dengan persepsi baik tentang Program JKN lebih memanfaatkan kartu JKN-KIS. Penelitian ini sejalan dengan penelitian Melinda (2016) bahwa terdapat hubungan antara persepsi dengan minat keikutsertaan atau pemanfaatan BPJS Kesehatan ( $p=0,009$; PR=7,862; 95\% CI $=1,631$ 37,905). Sehingga semakin besar minat seseorang dalam keikutsertaan BPJS maka semakin besar tingkat pemanfaatan kartu JKNKIS. Jadi, terdapat hubungan antara persepsi 
tentang Program JKN dengan pemanfaatan kartu JKN-KIS pada pasien rawat inap di RSUD Ungaran.

Hasil penelitian pada variabel kepemilikan kartu JKN-KIS tidak dapat dianalisis menggunakan uji chi-square karena tidak ada responden dengan tidak memiliki kartu JKN-KIS yang memanfaatkan kartu JKNKIS, sehingga tidak diketahui hubungan antara kepemilikan kartu JKN-KIS dengan pemanfaatan kartu JKN-KIS. Semakin meningkatnya peserta BPJS Kesehatan setiap tahunnya dan disertai dengan peningkatan pelayanan kepada pesertanya menyebabkan semakin meningkatnya pasien JKN-KIS yang memanfaatkan kartunya untuk mendapatkan pelayanan kesehatan di instalasi rawat inap RSUD Ungaran. Menurut penelitian Untari (2015), kelompok sosial ekonomi bawah banyak memiliki BPJS dikarenakan mereka merupakan Penerima Bantuan Iuran (PBI). Adapun kelompok yang harus membayar iuran secara mandiri masih sedikit dan ditemukan tingkat kesadaran masyarakat yang rendah untuk mengikuti kepesertaan BPJS.

Sebagian besar responden (78,7\%) memiliki kartu JKN-KIS dengan $8 \%$ responden tidak memanfaatkan kartunya dan 70,7\% responden memanfaatkan kartunya untuk mendapatkan pelayanan kesehatan di instalasi rawat inap RSUD Ungaran. Pasien dengan kepemilikan kartu JKN-KIS sudah menjadi peserta BPJS Kesehatan rata-rata selama 2,2 tahun sejak adanya BPJS Kesehatan yaitu 1 Januari 2014. Pasien yang tidak memiliki kartu JKN-KIS disebabkan karena 50\% responden merasa proses yang panjang dan melelahkan karena berlaku sistem rujukan berjenjang sehingga tidak mau mengurus, $25 \%$ responden tidak ingin membayar iuran/premi setiap bulannya, dan $25 \%$ responden baru akan membuat ketika sudah sakit, punya asuransi kesehatan lain, dan tidak cocok dengan pelayanan kesehatan dari BPJS Kesehatan.

Seperti halnya variabel kepemilikan kartu JKN-KIS, pada variabel status keaktifan kartu JKN-KIS juga tidak dapat dianalisis menggunakan uji chi-square karena responden dengan status keaktifan tidak aktif secara langsung tidak dapat memanfaatkan kartu JKNKIS, sehingga tidak diketahui hubungan antara status keaktifan kartu JKN-KIS dengan pemanfaatan kartu JKN-KIS. Dari hasil penelitian ini diketahui terdapat 19 orang (25,3\%) dengan status kartu tidak aktif dikarenakan $15,8 \%$ ada tunggakan pembayaran iuran, $21,05 \%$ calon peserta (belum melakukan pembayaran iuran pertama), dan $63,15 \%$ tidak memiliki kartu JKN-KIS. Selain itu, terdapat 3 responden (4\%) dengan status kartu aktif namun tidak memanfaatkan kartunya untuk mendapatkan pelayanan kesehatan di instalasi rawat inap di RSUD Ungaran dikarenakan merasa akan mengalami proses yang berbelitbelit dan memakan waktu yang lama apabila menggunakan BPJS dan merasa kurang puas terhadap pelayanan kesehatan dengan menggunakan JKN-KIS seperti tidak mendapat kamar yang sesuai untuk perawatan rawat inap sehingga memilih membayar sendiri dan menggunakan pelayanan kesehatan umum. Ketidakaktifan kartu JKN-KIS dapat terjadi apabila pemilik kartu tersebut tidak mematuhi prosedur pembayaran sesuai jangka waktu yang telah ditetapkan oleh BPJS yaitu paling lambat tanggal 10 setiap bulannya (Kemenkes dan JKN, 2012).

Pada variabel promosi BPJS Kesehatan diketahui bahwa nilai $p(0,023)<\alpha(0,05)$ dan interval kepercayaan 1,053 - 2,114 (tidak mencakup angka 1), yang artinya ada hubungan antara promosi BPJS Kesehatan dengan pemanfaatan kartu JKN-KIS dan diperoleh nilai PR (Prevalence Ratio) sebesar 1,492, artinya pasien yang pernah mendapat informasi atau promosi mengenai BPJS Kesehatan memiliki peluang 1,492 kali untuk memanfaatkan kartu JKN-KIS di RSUD Ungaran. Penelitian ini sejalan dengan hasil penelitian Tumbuan (2016) yang menunjukkan bahwa terdapat hubungan antara promosi BPJS Kesehatan dengan pemanfaatan layanan BPJS Kesehatan di RSUD Amurang Kabupaten Minahasa Selatan ( $p$-value 0,000 atau $p<0,05$ dengan tingkat kesalahan $\alpha$ $0,05)$. Namun, penelitian ini tidak sesuai dengan penelitian yang dilakukan oleh Tasya (2016) 
bahwa faktor pemanfaatan mengenai informasi keberadaan tidak memiliki hubungan yang signifikan dengan pemanfaatan pelayanan kesehatan gigi dan mulut oleh pasien di Rumah Sakit Gigi dan Mulut (RSGM) Universitas Syiah Kuala Banda Aceh.

Promosi serupa dengan komunikasi keduanya memiliki kesamaan yakni merupakan sebuah teknik untuk menyampaikan informasi mengenai sesuatu kepada masyarakat (Sunardi, 2015 dalam Tumbuan, 2016). Perencanaan komunikasi diperlukan untuk menyosialisasikan Program JKN karena kepesertaan bersifat wajib bagi seluruh masyarakat Indonesia pada tahun 2019. Promosi atau komunikasi interpersonal maupun menggunakan media seperti televisi, koran, radio dan sebagainya diperlukan agar semua masyarakat menjadi peserta atau dengan kata lain promosi memiliki hubungan dengan kepesertaan dan pemanfaatan layanan BPJS Kesehatan (Komariah, 2015). Sehingga terdapat hubungan antara promosi BPJS Kesehatan dengan pemanfaatan kartu JKN-KIS pada pasien rawat inap di RSUD Ungaran.

Berdasarkan hasil analisis bivariat pada variabel kepuasan terhadap pelayanan kesehatan diketahui nilai $p(0,039)<\alpha(0,05)$ dan interval kepercayaan 0,543-0,915 (tidak mencakup angka 1), yang artinya ada hubungan antara kepuasan terhadap pelayanan kesehatan rumah sakit dengan pemanfaatan kartu JKNKIS dan diperoleh nilai PR (Prevalence Ratio) sebesar 0,705 , artinya pasien yang puas terhadap pelayanan kesehatan di rumah sakit memiliki peluang 0,705 kali untuk memanfaatkan kartu JKN-KIS di RSUD Ungaran. Hasil penelitian ini sejalan dengan penelitian Sardiawan (2015) bahwa ada hubungan yang bermakna antara dimensi mutu pelayanan dengan pemanfaatan pelayanan kesehatan pada poliklinik rawat jalan pasien peserta BPJS di Rumah Sakit Siloam Bali dengan niai $p=0,000$ atau $<0,05$. Hasil penelitian ini juga sejalan dengan hasil penelitian Magan (2013) bahwa sarana prasarana dan sikap petugas ada hubungan dengan pemanfaatan pelayanan kesehatan. Penelitian yang dilakukan oleh Putri (2014) menunjukkan pengguna kartu JKN-KIS kategori PBI tidak mau mengurus pemanfaatan kartu JKN-KIS ini karena memiliki pengalaman yang kurang baik dengan produk jaminan kesehatan terdahulu seperti Jamkesmas maupun Jamkesda.

Menurut hasil penelitian diketahui bahwa dari 50 pasien $(66,7 \%)$ sudah merasa puas dan 31 pasien $(41,3 \%)$ diantaranya memanfaatkan JKN-KIS dan dari 25 pasien $(33,3 \%)$ merasa cukup puas terhadap pelayanan yang diperoleh dari rumah sakit dalam hal ini di RSUD Ungaran, 22 pasien $(29,3 \%)$ diantaranya memanfaatkan JKN-KIS sehingga faktor yang menguntungkan untuk memanfaatkan pelayanan kesehatan rumah sakit. Dari hasil wawancara terhadap pasien rawat inap di RSUD Ungaran, 57 responden (76\%) puas terhadap pelayanan dokter dan perawat, 48 responden (64\%) puas dengan pelayanan administrasi dan 43 responden $(57,3 \%)$ puas dengan ketersediaan sarana dan prasarana rumah sakit, namun 12 responden (16\%) merasa kurang puas dengan kebersihan kamar mandi/WC dan 17 responden (22,6\%) merasa cukup puas dengan kebersihan kamar mandi/WC, 6 responden (8\%) kurang puas dengan kenyaman rumah sakit dan 20 responden $(26,6 \%)$ cukup puas dengan kenyamanan rumah sakit 1 responden diantaranya yang mengeluhkan kebisingan dari kendaraan yang berlalu lalang karena letak ruang perawatan bersebelahan dengan jalan raya.

Pemanfaatan pelayanan kesehatan adalah hasil dari proses pencarian pelayanan kesehatan oleh seseorang maupun kelompok. Menurut Dever dalam Sardiawan (2015), faktor-faktor yang mempengaruhi seseorang dalam penggunaan pelayanan kesehatan adalah faktor sosiokultural, faktor organisasi dan faktor interaksi konsumen dengan petugas kesehatan. Pelayanan rumah sakit termasuk ke dalam faktor organisasi dan faktor interaksi konsumen dengan petugas kesehatan. Mutu pelayanan rumah sakit adalah salah satu strategi pemasaran untuk mempertahankan eksistensi rumah sakit. Efektivitas JKN melalui BPJS 
Kesehatan sangat berkaitan dengan pelayanan kesehatan bagi pengguna kartu JKN-KIS. Pelayanan yang diberikan oleh penyedia fasilitas kesehatan harus bersifat responsif, pelayanan yang tidak berbelit-belit sesuai dengan prosedur dan dengan akurasi waktu yang tepat dan cepat (Putri, 2014). Sehingga terdapat hubungan antara kepuasan terhadap pelayanan kesehatan dengan pemanfaatan kartu JKN-KIS pada pasien rawat inap di RSUD Ungaran.

\section{PENUTUP}

Terdapat hubungan antara pekerjaan, pengetahuan, sikap, persepsi tentang Program JKN, promosi BPJS Kesehatan, dan kepuasan terhadap pelayanan kesehatan rumah sakit dengan pemanfaatan kartu JKN-KIS pada pasien rawat inap di RSUD Ungaran. Tidak terdapat hubungan antara tingkat pendidikan dan tingkat pendapatan dengan pemanfaatan kartu JKN-KIS pada pasien rawat inap di RSUD Ungaran. Selain itu, tidak diketahui hubungan kepemilikan dan status keaktifan kartu JKN-KIS dengan pemanfaatan kartu JKN-KIS pada pasien rawat inap di RSUD Ungaran.

Terdapat faktor lain yang dikemukakan oleh para ahli lain yang ditemukan saat penelitian dan tidak diteliti dalam penelitian ini, seperti faktor kemudahan/akses terhadap fasilitas pelayanan kesehatan, pengaruh keluarga, dan perilaku. Maka saran untuk penulisan selanjutnya dengan penelitian sejenis disarankan untuk mengembangkan penelitian dengan menggunakan variabel baru begitu juga untuk sampel dan populasi.

\section{DAFTAR PUSTAKA}

Alfiati, Y., Marwati T., dan Solikhah. 2010. FaktorFaktor yang Mempengaruhi Pemanfaatan Pelayanan Poli Obsgyn di RSUD Banjarnegara. KESMAS, 4(3): 144-239

BPS Jawa Tengah. 2016. Provinsi Jawa Tengah Dalam Angka 2016. Jawa Tengah: BPS Provinsi Jawa Tengah

Kemenkes dan JKN. 2012. Buku Pegangan Sosialisasi
Jaminan Kesehatan Nasional (JKN) dalam Sistem Jaminan Sosial Nasional. Jakarta: Tim penyusun bahan sosialisasi dan advokasi JKN

Kementerian Kesehatan RI. 2009. Undang-Undang No. 44 Tahun 2009 Tentang Rumah Sakit. Jakarta: Kementerian Kesehatan RI

Komariah, S. 2015. Penerapan Komunikasi Badan Penyelenggara Jaminan Sosial (BPJS) Kota Balikpapan Dalam Mensosialisasikan Program Jaminan Kesehatan Nasional (JKN) Kepada Masyarakat Kota Balikpapan. Jurnal Ilmu Komunikasi (eJournal), 3(2): 107-121

Magan, H., Indar, dan Balqis. 2013. Faktor yang Berhubungan dengan Pemanfaatan Pelayanan Kesehatan Unit Rawat Jalan di Wilayah Kerja Puskesmas Makale. Jurnal Kesehatan Masyarakat (e-Journal), 8(3): 1-10

Melinda, Suparwati, A., dan Suryoputro, A. 2016. Faktor-Faktor yang Berhubungan Dengan Minat Masyarakat Dalam Keikutsertaan BPJS Mandiri di Kecamatan Bener Kabupaten Purworejo. Jurnal Kesehatan Masyarakat (eJournal), 4(4): 86-93

Pratiwi, A. dan Raharjo, B. B. 2017. Pemanfaatan Pusat Layanan Kesehatan (Puslakes) Universitas Negeri Semarang. HIGEIA, 1(4): 49-60

Putri, N. E. 2014. Efektivitas Penerapan Jaminan Kesehatan Nasional Melalui BPJS Dalam Pelayanan Kesehatan Masyarakat Miskin di Kota Padang. Tingkap, 10(2): 175-189

Quimbo, S., Florentino, J., Peabody, J. W., Shimkhada, R., Panelo, C., dan Solon, O. 2008. Underutilization of Social Insurance among the Poor: Evidence from the Philippines. The PLoS ONE Journal of Insurance Underutilization, 3(10): 1-4

Rumengan, S., Debra, S., Umboh, J. M. L., dan Kandou, G. D. 2015. Faktor-Faktor yang Berhubungan dengan Pemanfaatan Pelayanan Kesehatan Pada Peserta BPJS Kesehatan di Puskesmas Paniki Bawah Kecamatan Mapanget Kota Manado. JIKMU, 5(1): 88-100

Sampeluna, N., Balqis, dan Hamzah, A. 2013. Faktor-Faktor yang Berhubungan dengan Pemanfaatan Pelayanan Kesehatan di RSUD Lakipadada Kabupaten Tana Toraja. Jpkesmas (e-journal), 1(3): 1-14

Sardiawan, C. S. dan Hardy, P. D. K. 2015. Hubungan Persepsi Dimensi Mutu Pelayanan dengan Pemanfaatan Pelayanan Rawat Jalan pada Pasien Jaminan Kesehatan Nasional 
Rumah Sakit Siloam Bali. Jurnal Virgin, 1(2): 191-199

Septianingrum, M. dan Sari, A. N. 2015. Hubungan Pengetahuan Ibu Hamil Tentang Jaminan Kesehatan Nasional dengan Penggunaan Kartu BPJS Kesehatan di Desa Sobokerto Ngemplak, Boyolali Tahun 2015. Jurnal Akbidmus, 235-248

Sugiyono. 2009. Metode Penelitian Kuantitatif, Kualitatif dan $R \& D$. Bandung: Penerbit Alfabeta

Supariani, N. N. D. 2011. Faktor-Faktor yang Berhubungan dengan Pemanfaatan Pelayanan Kesehatan Gigi dan Mulut di Poliklinik Gigi RSUD Kabupaten Badung. Jurnal Skala Husada, 10(1): 20-24

Tasya, N., Andriany, P., dan Herwanda. 2016. Faktor-Faktor yang Berhubungan dengan Pemanfaatan Pelayanan Kesehatan Gigi dan Mulut di Rumah Sakit Gigi dan Mulut (RSGM) Universitas Syiah Kuala Banda
Aceh. Journal Caninus Dentistry, 1(4): 54-62

Tumbuan, V. J., Kolibu, F. K., dan Ratag, B. T. 2017. Hubungan Promosi BPJS Kesehatan dan Pengetahuan Pasien Dengan Pemanfaatan Layanan BPJS Kesehatan di RSUD Amurang Kabupaten Minahasa Selatan. Jurnal Kesehatan Masyarakat (e-Journal), 8(2): 1-8

Untari, I., dan Putri, A. H. 2015. Hubungan Antara Tingkat Sosial Ekonomi Keluarga Dengan Kepemilikan BPJS (Badan Penyelenggara Jaminan Sosial). Profesi, 13(1): 30-37

Vianey, Y. M. 2016. Pengetahuan dan Sikap Peserta BPJS dengan Motivasi Berobat ke Puskesmas Waipukang Kecamatan Ile Ape. Jurnal Kesehatan Masyarakat, 8(1): 1-14

Winardi, H., Hidayat, W., dan Wijayanto, A. 2014. Pengaruh Kualitas Pelayanan Terhadap Kepuasan Konsumen Pasien Rawat Inap di SMC Rumah Sakit Telogorejo. Jurnal Ilmu Administrasi Bisnis, 3(2): 1-6 